\title{
Macrophytic Distribution and Trophic State of Some Natural and Impacted Watercourses - Belgium Wallonia
}

\author{
Regular Paper
}

\author{
Khadija Sossey-Alaoui ${ }^{1, *}$ and Francis Rosillon ${ }^{1}$ \\ 1 Université de Liège, Département des Sciences et Gestion de l'Environnement, Arlon, Belgium \\ * Corresponding author E-mail: ksossey@ulg.ac.be
}

Received 13 Mar 2013; Accepted 7 Maj 2013

DOI: $10.5772 / 56609$

(C) 2013 Sossey-Alaoui and Rosillon; licensee InTech. This is an open access article distributed under the terms of the Creative Commons Attribution License (http://creativecommons.org/licenses/by/3.0), which permits unrestricted use, distribution, and reproduction in any medium, provided the original work is properly cited.

\begin{abstract}
In the present paper we investigated macrophyte community structure in 60 natural and impacted stream and river sites distributed throughout the Walloon river network.

The objectives were to describe the distribution of macrophyte assemblages in relation to physico-chemical parameters of their environment and to assess the variability in ecological metrics within these watercourses.

Two-way clustering allowed us to simultaneously assign sample units and species to groups by performing two separate cluster analyses. Indicator species analysis allowed us to assess the degree to which a species indicated a group, based on its constancy and distribution of abundance.

Six end-groups were identified as a result of using twoway clustering and indicator species analysis techniques. Hygroamblystegium fluviatile, Chiloscyphus polyanthos and Lemanea fluviatilis were found to characterize acidic and low impacted streams and rivers (G1), while Ranunculus fluitans was found in all low impacted large streams (G2). Potamogeton pectinatus, proved to be more common in eutrophicated waters in the calcareous areas particularly in the "Loess low plateaux" region (G6).
\end{abstract}

Cinclidotus riparius, Fissidens crassipes and Pellia endiviifolia, appeared in rivers situated in the Condroz region (G4), which was characterized by a high concentration of nitrogen.

Keywords Water Framework Directive (WFD), Macrophytes, Walloon Network, Ecological Quality, Rivers

\section{Introduction}

The European Union (EU) Water Framework Directive (WFD), which came into force in December 2000 [1], requires European Member States to assess the "ecological status" of their country's surface waters.

The main focus of the WFD is the use of biological quality elements (macrobenthic fauna, fish and aquatic flora) in stream assessment, which is a concept new to many European countries [2]. As part of the WFD, aquatic macrophytes are considered as one of the biological quality elements for which an assessment of status must 
be made. Macrophytes have been studied not only in the context of lake and ditch trophic systems [3-5], alkalinity [6] and acidification but also as indicator species or as vegetation in running waters [7-15].

As in most of the countries in Western Europe, the study of aquatic macrophytes has long since been abandoned in Wallonia. Macrophytes have been used as key bioindicators for assessing global water quality [16-21]. Nevertheless, many of these existing studies deal mainly with phanerogames or bryophytes, while only a few focus on all the macrophyte groups (phanerogames, macro-algae, mosses and liverworts).

For the purposes of implementing the WFD, macrophyte data was collected from several stream and river sites throughout Wallonia. The Macrophyte Biological Index for Rivers (MBIR) [22 and 23] was used to define the ecological status of rivers in response to eutrophication pressure.

The purpose of this study was i) to categorize the watercourses analysed according to their floristic composition, ii) to identify the characteristics of their macrophyte assemblage and iii) to identify physicochemical parameters in relation to macrophyte distribution.

\section{Material and methods}

\subsection{Macrophyte and environmental database}

Surveys were conducted on 60 sites along 100m stretches, which included both swift and slow flowing habitats.

The sampling sites were distributed throughout the Walloon network and covered the five natural regions: the Loess low plateaux, the Condroz, the Famenne, the Ardennes and the Jurassic regions. These five areas correlate well to the geological differences between the calcareous areas of Wallonia and were characterized as indicated in Figures 1 and 2, Table 1 and electronic appendix 1 .

The sites were selected in order to provide relevant and representative hydrological and geographical coverage according to the monitoring networks of Walloon rivers.

Macrophyte surveys were undertaken using the protocols associated with the Macrophyte Biological Index for Rivers (MBIR) indexation method [22 and 23].

The submerged macrophytes were surveyed twice during the main vegetation period in 2009-2012.

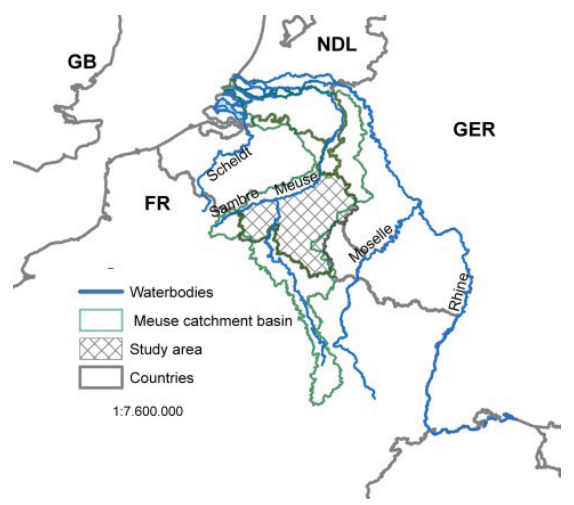

Figure 1. Study area

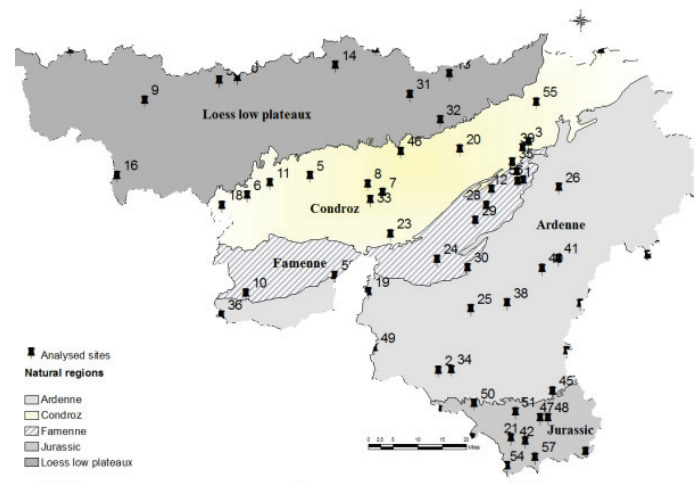

Figure 2. Sites analysed

Percentage cover was estimated in the field for all the macrophyte taxa, and classified according to a scale of cover, ranging from one to five [22]. The nomenclature used follows the literature for spermatophytes [25], for bryophytes [26] and for algae [27].

In each botanical sampling site, several physico-chemical variables were analysed: nitrite $(\mathrm{mgN} / \mathrm{l})$, nitrate $(\mathrm{mgN} / \mathrm{l})$, ammonium (mgN/l), conductivity $(\mu \mathrm{s} / \mathrm{cm}), \mathrm{pH}$, Complete Title Alcalimetric $(\mathrm{TAC})\left({ }^{\circ} \mathrm{F}\right)$, calcium $(\mathrm{mg} / \mathrm{l})$, magnesium $(\mathrm{mg} / \mathrm{l})$ and $\mathrm{P}-\mathrm{PO} 4^{3}{ }^{3}(\mathrm{mgP} / \mathrm{l})$.

Different environmental variables were also estimated: stream width (five modalities: $\leq 1 \mathrm{~m}, 1.1$ to $3 \mathrm{~m}, 3.1$ to $5 \mathrm{~m}$, 5.1 to $8 \mathrm{~m}$ and $>8 \mathrm{~m}$ ), stream depth (five modalities: $\leq$ $0.1 \mathrm{~m}, 0.11$ to $0.3 \mathrm{~m}, 0.31$ to $0.5 \mathrm{~m}, 0.51$ to $1 \mathrm{~m}$ and $>1 \mathrm{~m}$ ), riverside land cover (grassland, grassland and deciduous, deciduous forest, deciduous and coniferous forest and urbanized area), luminosity (four modalities: $\leq 25 \%, 26$ to $50 \%, 51$ to $75 \%$ and $>75 \%$ ) (Appendix 1 ).

\subsection{Statistical analysis}

The distribution of macrophytic communities in the different watercourses sampled was analysed by twoway clustering analysis (PC-ORD [28]). 


\begin{tabular}{|c|c|c|c|c|c|c|c|c|c|c|}
\hline $\begin{array}{l}\text { Natural } \\
\text { region }\end{array}$ & $\begin{array}{l}\text { Region } \\
\text { surface } \\
\text { area \% }\end{array}$ & $\begin{array}{l}\text { Forests } \\
\%\left(^{*}\right)\end{array}$ & $\begin{array}{c}\text { Cultivated } \\
\text { areas } \%\end{array}$ & $\begin{array}{c}\text { Grass } \\
\text { lands } \\
\%\end{array}$ & $\begin{array}{c}\text { Built-up } \\
\text { areas } \\
\%(* *)\end{array}$ & $\begin{array}{l}\text { Miscellaneous } \\
\%(* * *)\end{array}$ & $\begin{array}{l}\text { Altitude } \\
\text { m (mean) }\end{array}$ & $\begin{array}{l}\text { Prevailing } \\
\text { geology }\end{array}$ & $\begin{array}{l}\text { Other } \\
\text { geology }\end{array}$ & Soils \\
\hline $\begin{array}{l}\text { Loess low } \\
\text { plateaux }\end{array}$ & 30.3 & 10.8 & 57.3 & 17.7 & 10.5 & 3.7 & $\begin{array}{c}20-200 \\
(100)\end{array}$ & Tertiary & Cretaceous & $\begin{array}{l}\text { Silt, sand-silt } \\
\text { (locally } \\
\text { calcareous- } \\
\text { laden) }\end{array}$ \\
\hline Condroz & 20.3 & 26.1 & 23.8 & 37.5 & 8.9 & 3.7 & $\begin{array}{c}100-350 \\
(250)\end{array}$ & $\begin{array}{l}\text { Carboniferous } \\
\text { Upper and } \\
\text { Middle } \\
\text { Devonian }\end{array}$ & $\begin{array}{l}\text { Cretaceous } \\
\text { (Plateau de } \\
\text { Herve) }\end{array}$ & $\begin{array}{l}\text { Schist, } \\
\text { calcareous, } \\
\text { psammite } \\
\text { (+ calcareous } \\
\text { clay in } \\
\text { Plateau } \\
\text { de Herve) }\end{array}$ \\
\hline Famenne & 11.3 & 41.9 & 14.5 & 38.2 & 2.6 & 2.7 & $\begin{array}{c}100-250 \\
(200)\end{array}$ & $\begin{array}{l}\text { Upper and } \\
\text { Middle } \\
\text { Devonian }\end{array}$ & & $\begin{array}{l}\text { Schist, } \\
\text { calcareous, } \\
\text { clay }\end{array}$ \\
\hline Ardennes & 33.4 & 58.5 & 3.6 & 34.6 & 1.1 & 2.3 & $\begin{array}{c}200-694 \\
(400)\end{array}$ & $\begin{array}{l}\text { Lower } \\
\text { Devonian, } \\
\text { Cambrian }\end{array}$ & $\begin{array}{l}\text { Ordovician, } \\
\text { Silurian }\end{array}$ & $\begin{array}{l}\text { Schist, } \\
\text { phyllade, } \\
\text { siliceous } \\
\text { (sandstone, } \\
\text { quartzite) }\end{array}$ \\
\hline Jurassic & 4.7 & 38.6 & 10.4 & 43.9 & 3.3 & 3.8 & $\begin{array}{c}195-465 \\
(300)\end{array}$ & Jurassic & & $\begin{array}{l}\text { Schist, clay, } \\
\text { marl (locally } \\
\text { calcareous) }\end{array}$ \\
\hline
\end{tabular}

Table 1. The five natural regions in Wallonia [24].

This method allowed us to simultaneously assign sample units and species to groups by performing two separate cluster analyses. Indicator species analysis was used to assess the degree to which a species indicated a group, based on its constancy and distribution of abundance [29] (PC-ORD; [28]).

Principal component analysis was performed to characterize the different groups according to the physico-chemical parameters of their environment. The ecological metric calculated was the mean Macrophyte Biological Index for Rivers [22]. This metric is based on information regarding species tolerance to eutrophication. The metric was developed in France to assess water eutrophy and organic pollution in rivers and was applied in Wallonia. MBIR scores vary between 0 (degraded) and 20 (high quality) [22].

\section{Results}

\subsection{Floristic assemblage and physico-chemical results}

Helophytes and species that occurred less than three times were removed from the analysis. Stations with less than three species were also discarded. Only 30 taxa were kept; they included 13 bryophytes, 12 phanerogams and five macroalgae.

Using two-way-clustering analysis, we identified six groups on the basis of their macrophytic composition (Figure 3). The most characteristic species in each group were then determined using Indicator Species Analysis. Finally, Principal Component Analysis (PCA) was used to characterize the different physico-chemical groups (Figure 4).

Group 1 (Figure 3) comprise stations mainly in the Ardenne region whose water originates from groundwater in Eodevonian slatey sandstone, slatey quartz or phillite slate formations. The typical macrophytic community in this group included a moss (Hygroamblystegium fluviatile), a liverwort (Chiloscyphus polyanthos), a red alga (Lemanea fluviatiles) and, to a lesser extent, Fontinalis squamosa, Ranunculus penicillatus, Riccardia chamaedryfolia and Stigeoclonium sp. The watercourses of this group were characterized by low mineral content water, a low to medium buffer capacity and low levels of phosphorus and nitrogen compounds.

Group 2 includes calcareous and non-calcareous rivers, which were characterized by the macroalga Oedogonium sp.

As in the case of Groups 4, 5 and 6, the stations in Group 3 are in silty calcareous, marly calcareous or slatey calcareous formations with high conductivity and a high calcium bicarbonate load. The macroalga Cladophora glomerata was common to all stations. This group could be split into three subgroups, based on trophic levels: i) the first subgroup (sg1) was made up of sites on major rivers characterized by the high occurrence and abundance of 
Ranunculus fluitans, ii) the second subgroup (sg2) included stations on rivers flowing mainly on the Loess low plateaux, characterized by the algal proliferation of Cladophora glomerata (as long filaments) and iii) the third subgroup (sg3) covered the Rabais and the Lamfranba, two rivers from the Jurassic region, characterized by Cratoneuron filicinum, Fissidens crassipes and Pellia endiviifolia. In terms of chemicals, the stations in Subgroups 1 and 3 had low levels of phosphorus and nitrogen compounds, but those in Subgroup 2 had highly eutrophic waters $(0.06-0.57 \mathrm{mgP} / 1$ orthophosphates and 0.05-3.27mg N/l ammonium nitrogen).

The most characteristic macrophytic community in Group 4 comprised Callitriche platycarpa, Potamogeton crispus and Sparganium emersum. It also included Elodea nuttallii, Pellia endiviifolia and Myriophyllum spicatum, but at a lower occurrence. The stations in this group were located in the Jurassic region on slatey-clayey-marly soils and the water had a high mineral content (average conductivity ranging between 465 and $537 \mu \mathrm{s} / \mathrm{cm}$ ).

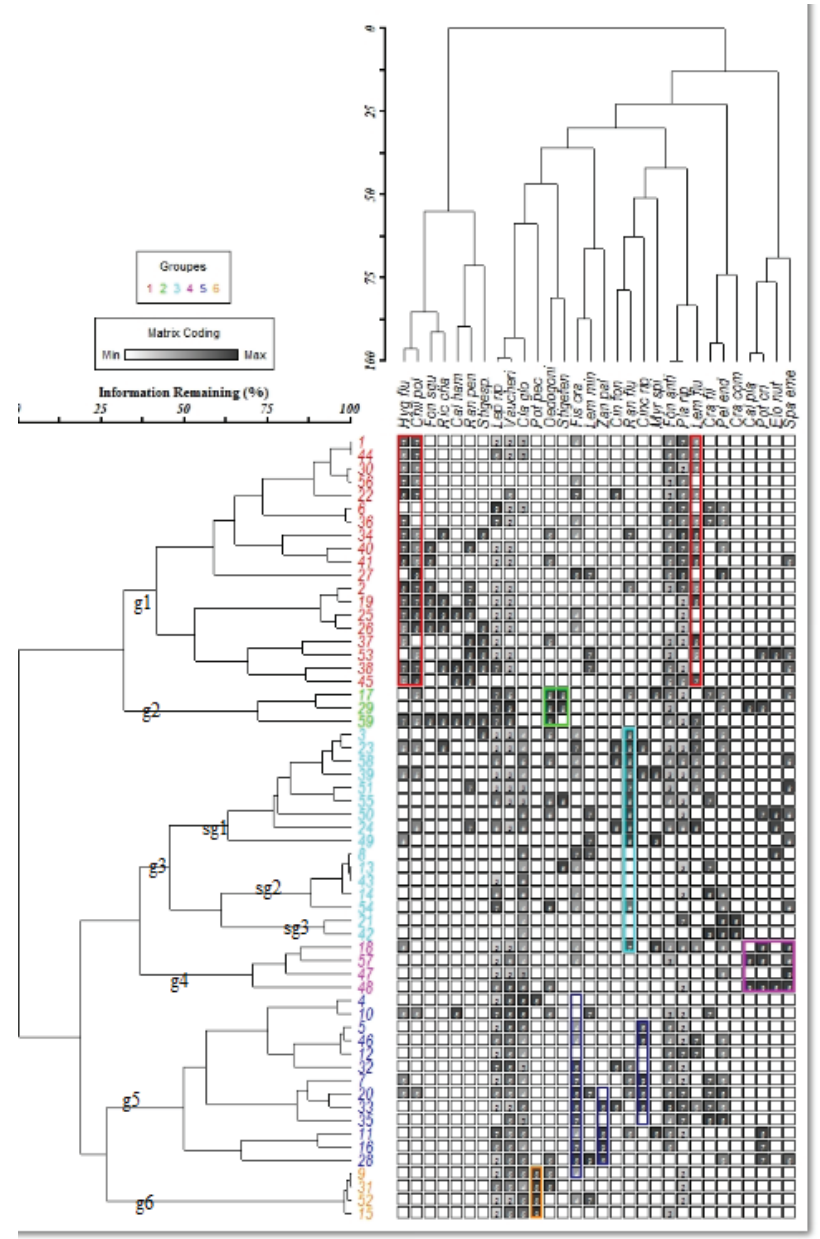

Figure 3. Two-way clustering results. The intensity of the colour of the circles reflects the abundance of each species. The full name of the species appears in electronic appendix 2.
The streams in Group 5 were situated in the Condroz region and are characterized by high nitrate levels. The characteristic community of this group consisted of Cinclidotus riparius, Fissidens crassipes, Pellia endiviifolia and Zannichellia palustris. In addition to high alkalinity and high mineralization, the Group 5 stations are characterized by high nitrate content.

Potamogeton pectinatus was typical of the Group 6 sites. These sites have highly mineralized water (flowing on Jurassic and Loess low plateaux limestone and showing strong eutrophication). The following taxa were also observed at the Group 6 stations: the moss Leptodictyum riparium and two macroalgae, Vaucheria sp. and Cladophora glomerata.
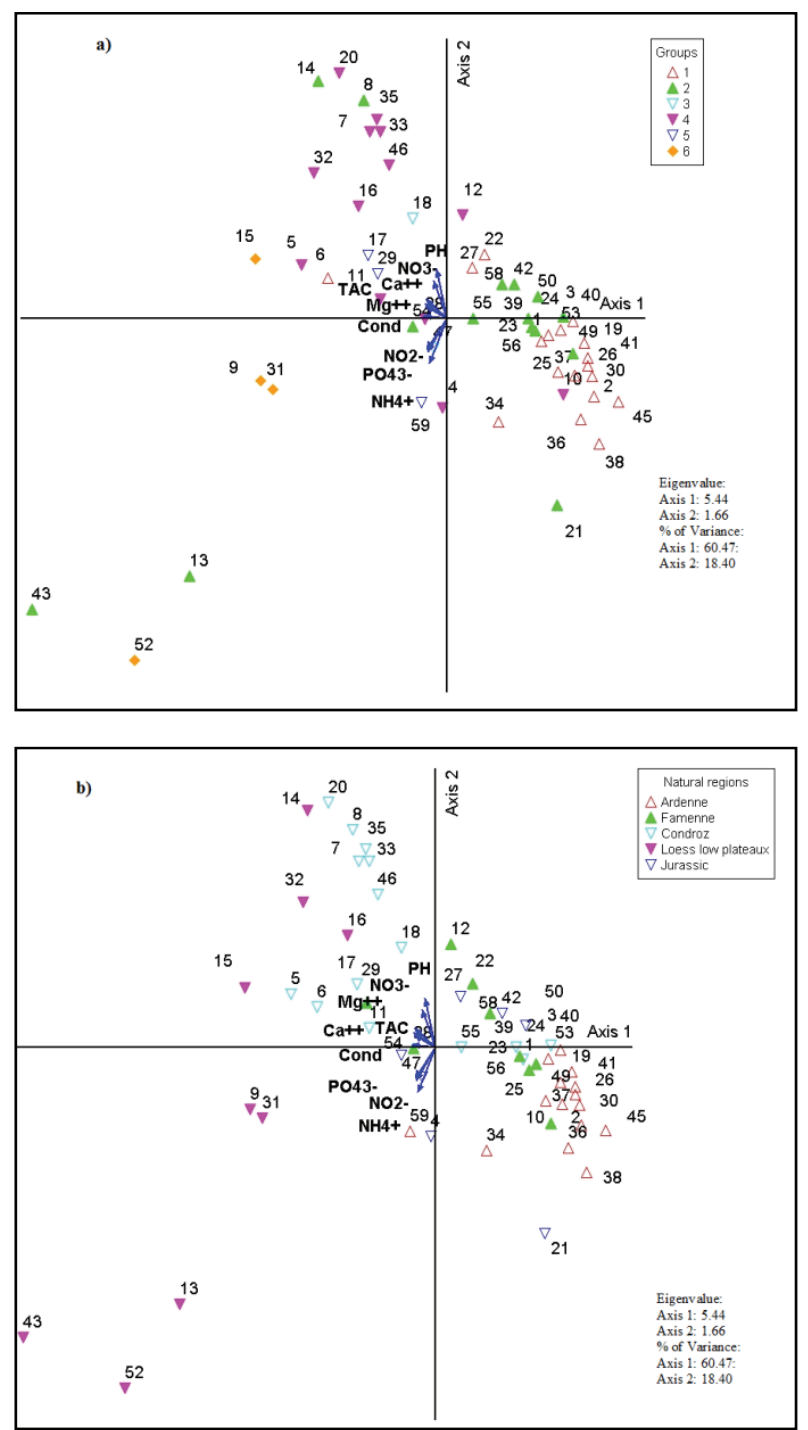

Figure 4. Outcome of the Principal Component Analysis applied to the physico-chemical data of 55 out of the 60 stations under study. Sites are colour-coded to differentiate the six groups of stations as determined by Two-way clustering Analysis (a) and by their location in the natural regions (b). 
The following species ('ubiquitous species') occurred in more than three out of the six groups: the mosses Platyhypnidium riparoides, Leptodictyum riparium and Fontinalis antipyretica and a macroalga belonging to the Vaucheria genus.

\subsection{MBIR results}

Macrophyte biological indices were calculated for each site and four trophic states were detected in all the monitored stations. Only $1 \%$ of sites showed a high quality trophic state, $19 \%$ showed a good state, with a high occurrence in the Ardennes area (gI), 31\% showed a moderate state and $25 \%$ of the sites showed a poor trophic state, with a high occurrence in the Jurassic and the Loess low plateaux regions.

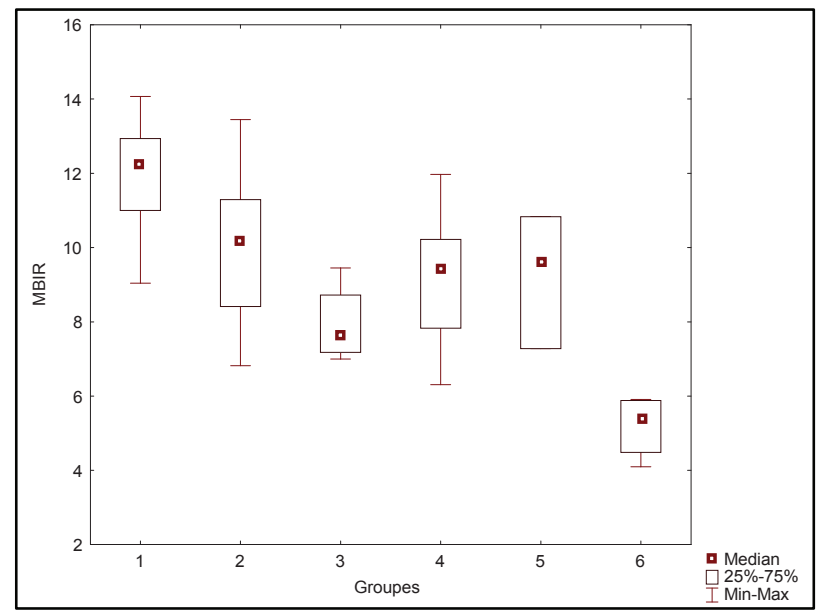

Figure 5. Variation in trophic level between the six groups

A box-whisker plot test (Figure 5) showed a significant difference between the six groups (Kruskal-Wallis test, $\mathrm{p}<0.005)$. The MBIR scores were slightly higher in the a priori defined gI group, corresponding to the Ardennes sites and lower in the end-defined group, corresponding to the watercourses of the Jurassic and Loess low plateaux regions (Group 6).

The linear relationship of the MBIR index to the physicochemical parameters was quantified using Spearman's coefficient of correlation (Table 2).

$\begin{array}{cc}\text { Physico-chemical parameters } & \text { MBIR } \\ \text { PH } & -\mathbf{0 . 1 8} \\ \text { Conductivity } & -\mathbf{0 . 6 6 ^ { * * }} \\ \text { Ammoniacal nitrogen } & -\mathbf{0 . 8 1 ^ { * * * }} \\ \text { Nitrates } & -0.23^{*} \\ \text { Nitrites } & -\mathbf{0 . 8 0 ^ { * * * }} \\ \text { Soluble orthophosphates } & -\mathbf{0 . 7 2} \mathbf{2}^{* * *} \\ \text { Magnesium } & -\mathbf{0 . 5 8 ^ { * * }} \\ \text { Calcium } & -\mathbf{0 . 5 8 ^ { * * }} \\ \text { Complete Title Alcalimetric } & -\mathbf{0 . 5 4 * *}\end{array}$

Table 2. Significant Spearman's rank correlation coefficients between environmental characteristics and MBIR. Probability levels used: ${ }^{*} \mathrm{p}<0.05 ;{ }^{* *} \mathrm{p}<0.01 ;{ }^{* * *} \mathrm{p}<0.001$.
A highly negative correlation was observed between the MBIR value calculated for each of the analysed sites and all the analysed parameters. Nevertheless, this correlation was lower with nitrates and $\mathrm{pH}$.

\section{Discussion}

Our investigations showed that macrophytes occurred in most of the streams and rivers studied. We also noted that their abundance could be constrained by unfavourable environmental conditions (high anthropic pressure and shading by the riparian vegetation).

To gain a better understanding of the differences attributable to environmental conditions (e.g., geology) and to external pressures on water courses and their plant components, we looked at the different groups of stations in terms of the physical and chemical conditions of the environment, the geology and land use at the level of the watershed.

The distribution of stations and macrophytic species showed a division between the stations with acidic water (G1) and those with alkaline water (G2-G6). This division could be explained geologically (Ardenne stations with water flowing from water tables in Eodevonian slatey sandstone, slatey quartz or phillite slate formations (G1), or from other regions located on silty calcareous, marly calcareous and slatey calcareous formations (G2 to G6), but also by the type and degree of environmental disturbance (differences among the three groups of stations with water courses flowing on calcareous substrates).

Group 1 was characterized by a community dominated by mosses and liverworts and by a higher plant Ranunculus penicillatus. The natural ecological properties of this area (altitude, climate, trophic level, etc.) are substantially different from those of other parts of Wallonia. Its particular, features such as acidic soils and therefore acidic water, its high altitude and its extreme climate make it a truly autonomous entity. Watercourses at these heights are still relatively undegraded because of low housing and industrialization pressures and significant forest and grass cover. These characteristics are reflected in the type of vegetation in these generally unspoilt streams. Most of the rivers in this area are within the reference sites under the implementation of the Water Framework Directive.

The ecological tendencies of most macrophytes found matched the findings of previous studies. The occurrence of the mosses and liverworts Chiloscyphus polyanthus and Hygroamblystegium fluviatile in the Ardennes upstream area is corroborated by the literature [30-33]. 
The comparison of plant communities in this group with those described by Birk \& Willby [33] as being the 'Siliceous mountain brooks' type (R-C3) in the Central and Western Europe and the Baltic region group of countries, shows many similarities and a few differences. The similarities relate to the floristic composition of mosses and liverworts. Most species associated with the R-C3 European type were also observed at the sites of this group; these sites can therefore be linked to the R-C3 type.

There was a discrepancy, however, with regard to the vascular plant Ranunculus penicillatus. Birk \& Willby [33] classified this species in river communities of the 'Medium-sized lowland streams' (R-C4) type. In our region, however, $R$. penicillatus is considered to be characteristic of the Ardennes streams [21, 25 and 34]. It has been observed frequently and in great abundance in Ardennes streams, but occurs less frequently and less abundantly in 'Medium-sized lowland streams' (R-C4) type watercourses.

The remaining five groups (G2-G6) had a more or less limy subsoil in common. They were located in natural regions characterized by silty limestone, marly limestone or slatey calcareous formations. According to reference [34], water from these areas share similar chemical characteristics. This also applies to vegetation. The observed differences therefore stemmed from varying levels and types of pressure on the natural environment and, consequently, on the vegetation.

For example, Group 5 included stations located mainly in the Condroz region. The landscape of this region is a mosaic of environments where crops, grassland, forest edges and streams alternate. The morphology of this particular area is linked to the succession of sandstone plateaux, occupied mainly by crops or by deciduous woodlands with rocky outcrops and calcareous depressions dominated by grasslands on clay loam less suitable for crops. This resulting high concentration of nitrates enriches the water in the area. There is a community of species specific to these environments.

A review of our results showed that some nitrate-rich sites (Group 5) contained natural species in terms of the MBIR index [22]. We identified Cratoneuron filicinum, Chiloscyphus polyanthus, Cinclidotus riparius, Fissidens crassipes and Hygrohygroamblystegium fluviatile. This accords with findings reported by reference [35], who showed that nitric nitrogen plays no role in determining aquatic vegetation and that its concentration gradients often run counter to the eutrophication series. They also noted that oligotrophic vegetation dominated by Potamogeton coloratus or $P$. polygonifolius is often characterized by nitrate rates equal to or greater than those found in more eutrophic sites. Eco-physiological tests have confirmed that most oligotrophic species have a high nitrate reductase activity [36].

Group 6, however, brings together highly mineralized nutrient-rich sites (located on Jurassic and Loess low plateaux calcareous soils). The naturally eutrophic water found in the limestone soils of both regions has become polytrophic in many places because of human influence (fertilizers, and man-made and industrial effluents). The rivers in these two regions are also highly anthropized. The longitudinal (and transversal) reshaping of rivers has completely changed the natural environmental conditions. These changes, combined with strong light, laminar flow and a sandy-gritty substrate have favoured some opportunistic pollution-tolerant species (e.g., Potamogeton pectinatus) and caused the disappearance of the most sensitive species.

It has been shown that man's alterations to rivers through impoundments, realignment of channels and in-stream engineering works can alter depth, velocity, substrate type, flow types and flow variability [37, 38]. These variables define the physical niches in rivers. Macrophytes have known preferences for these variables [39-40].

Alteration amounts to, inter alia, a simplification of flows (facies) and therefore of the aquatic habitats [37 and 38]. This facies homogenization leads almost directly to a simplification of aquatic biota and a drastic decline in biodiversity and biomass [41 and 42]. At sites in this region, $P$. pectinatus is showing a high recovery rate $(>30 \%)$, as has also been reported by the literature [42-45].

Baatrtrup-Pedersen \& Riis [42] analysed the abundance, composition and diversity of aquatic macrophytes in regulated and natural watercourses. They showed that species richness and Shannon's diversity index were very low in regulated streams. They also showed a positive correlation between substrate homogeneity and reduced diversity.

\section{Conclusion}

Species distribution along the 60 watercourses studied was linked to the nature of the geological formations crossed by the rivers and to the degree and nature of the pressure exerted on these environments. There was a clear difference between the Ardennes streams draining slatey sandstone, slatey quartz or phillite slate formations and those flowing on silty limestone, marly limestone or slatey calcareous formations (Jurassic, Condroz, Famenne and Loess low plateaux regions). The importance of forest and grass cover along the Ardennes watercourses and their low degradation favours the development of natural vegetation. 
In the four groups where the watercourses flow on silty calcareous, marly calcareous or slatey calcareous formations (Jurassic, Condroz, Famenne and Loess low plateaux), the observed differences were related to the type and degree of pressure on the ecosystem.

In Condroz (Group 4), the environment is dominated by crops and grasslands. The characteristic community is specific and less resistant than the one in the Loess low plateaux region or the Jurassic, where pressure is high (eutrophication, artificialization of banks, etc.). Group 6, however, comprised the most highly eutrophized sites (located in the Jurassic and Loess low plateaux natural regions) and was characterized by the most resistant species.
The results of the Macrophyte Biological Index for River (MBIR) calculated for the sites in the different groups corroborate the physico-chemical quality measured for each of the these groups. The trophic level was low in Group 1 for rivers in the Ardennes and very high for the sites in the Loess low plateaux region.

\section{Acknowledgements}

We would like to thank the Walloon region, which supported this study. The study was carried out as a result of a collaboration between the Department of Sciences and Environmental Management at Liege University (ULg) and the Walloon Public Service (SPW).

\begin{tabular}{|c|c|c|c|c|c|c|c|c|c|c|c|c|c|}
\hline $\mathrm{N}^{\circ}$ & $\begin{array}{c}\text { Water } \\
\text { courses }\end{array}$ & land cover & luminosity & \begin{tabular}{|l|} 
stream \\
width \\
classes
\end{tabular} & \begin{tabular}{|l} 
stream \\
depth \\
classes
\end{tabular} & $\mathrm{x}$ & $\mathrm{y}$ & $\begin{array}{l}\text { Natural } \\
\text { regions }\end{array}$ & $\begin{array}{c}\text { Forests } \\
\%\end{array}$ & $\begin{array}{c}\text { Cultivated } \\
\text { areas \% }\end{array}$ & \begin{tabular}{|c|}
$\begin{array}{c}\text { Grass } \\
\text { lands } \\
(\%)\end{array}$ \\
\end{tabular} & \begin{tabular}{|c|} 
Built- \\
up \\
areas \\
$\%$ \\
\end{tabular} & $\begin{array}{c}\text { Miscellaneous } \\
\%\end{array}$ \\
\hline 19 & Houille & $\begin{array}{c}\text { Deciduous and coniferous } \\
\text { forest }\end{array}$ & 1 & 4 & 2 & 184369 & 81541 & Ardennes & \multirow{15}{*}{58.5} & \multirow{15}{*}{3.6} & \multirow{15}{*}{34.6} & \multirow{15}{*}{1,1} & \multirow{15}{*}{2,3} \\
\hline 26 & Lienne & $\begin{array}{c}\text { Deciduous and coniferous } \\
\text { forest }\end{array}$ & 2 & 5 & 3 & 247000 & 115934 & Ardennes & & & & & \\
\hline 2 & Aleines & $\begin{array}{c}\text { Deciduous and coniferous } \\
\text { forest }\end{array}$ & 2 & 4 & 3 & 207339 & 55685 & Ardennes & & & & & \\
\hline 25 & LhommeHat & Grassland and deciduous & 2 & 5 & 2 & 218036 & 76027 & Ardennes & & & & & \\
\hline 30 & \begin{tabular}{|l|} 
Masblette \\
\end{tabular} & Grassland and deciduous & 2 & 4 & 2 & 216867 & 89585 & Ardennes & & & & & \\
\hline 34 & Muno & Deciduous forest & 2 & 4 & 2 & 211494 & 56057 & Ardennes & & & & & \\
\hline 36 & Oise & Grassland and deciduous & 1 & 2 & 2 & 135869 & 73981 & Ardennes & & & & & \\
\hline 37 & Our & Zone urbanisée & 3 & 5 & 1 & 276250 & 93694 & Ardennes & & & & & \\
\hline 40 & OurthOrtho & $\begin{array}{c}\text { Deciduous and coniferous } \\
\text { forest }\end{array}$ & 3 & 5 & 2 & 241519 & 89373 & \multirow{2}{*}{\begin{tabular}{|l|l|} 
& Ardennes \\
& Ardennes \\
\end{tabular}} & & & & & \\
\hline 38 & OurthBonner & Grassland & 2 & 4 & 2 & 230018 & 77900 & & & & & & \\
\hline 41 & Outheorr & $\begin{array}{c}\text { Deciduous and coniferous } \\
\text { forest }\end{array}$ & 2 & 5 & 2 & 246695 & 92492 & Ardennes & & & & & \\
\hline 45 & Rulles & Deciduous forest & 1 & 2 & 1 & 244912 & 49000 & Ardennes & & & & & \\
\hline 49 & SemoisBoh & Grassland and deciduous & 3 & 4 & 1 & 186134 & 63149 & Ardennes & & & & & \\
\hline 53 & Sûre & Grassland and deciduous & 3 & 4 & 3 & 249631 & 62108 & Ardennes & & & & & \\
\hline 59 & Wiltz & Grassland and deciduous & 3 & 4 & 3 & 254000 & 77706 & Ardennes & & & & & \\
\hline 3 & Amblève & Urbanized area & 3 & 5 & 3 & 237065 & 130806 & Condroz & \multirow{15}{*}{26.1} & \multirow{15}{*}{23.8} & \multirow{15}{*}{37.5} & \multirow{15}{*}{8.9} & \multirow{15}{*}{3,7} \\
\hline 5 & Biesme & Urbanized area & 3 & 4 & 2 & 165076 & 119744 & Condroz & & & & & \\
\hline 6 & Biesmelle & Deciduous forest & 1 & 4 & 2 & 144339 & 113277 & Condroz & & & & & \\
\hline 7 & Bocq & Deciduous forest & 1 & 5 & 2 & 189076 & 114221 & Condroz & & & & & \\
\hline 8 & Burnot & Deciduous forest & 2 & 3 & 2 & 184110 & 117040 & Condroz & & & & & \\
\hline 11 & Eau d'heure & Urbanized area & 3 & 5 & 3 & 151928 & 117399 & Condroz & & & & & \\
\hline 17 & \begin{tabular}{|l|} 
Gueule \\
\end{tabular} & Grassland & 3 & 4 & 3 & 260819 & 161238 & Condroz & & & & & \\
\hline 18 & Hantes & Grassland & 2 & 4 & 2 & 136135 & 110066 & Condroz & & & & & \\
\hline 20 & Houyoux & $\begin{array}{c}\text { Deciduous and coniferous } \\
\text { forest }\end{array}$ & 2 & 5 & 3 & 214436 & 128420 & Condroz & & & & & \\
\hline 23 & Lesse & Grassland and deciduous & 3 & 5 & 2 & 191526 & 100677 & Condroz & & & & & \\
\hline 33 & Molignée & Grassland and deciduous & 2 & 3 & 2 & 185003 & 111970 & Condroz & & & & & \\
\hline 35 & Neblon & Grassland and deciduous & 2 & 4 & 4 & 231673 & 124197 & Condroz & & & & & \\
\hline 39 & OurthCombl & Grassland & 3 & 4 & 3 & 235027 & 128914 & Condroz & & & & & \\
\hline 46 & \begin{tabular}{|l|} 
Samson \\
\end{tabular} & Grassland and deciduous & 3 & 4 & 2 & 194977 & 127726 & Condroz & & & & & \\
\hline 55 & Vesdre & Urbanized area & 3 & 5 & 3 & 239631 & 143935 & Condroz & & & & & \\
\hline
\end{tabular}




\begin{tabular}{|c|c|c|c|c|c|c|c|c|c|c|c|c|c|}
\hline $\mathrm{N}^{\circ}$ & Water courses & land cover & luminosity & \begin{tabular}{|l|} 
stream \\
width \\
classes
\end{tabular} & \begin{tabular}{|c|} 
stream \\
depth \\
classes
\end{tabular} & $\mathrm{x}$ & $\mathrm{y}$ & $\begin{array}{l}\text { Natural } \\
\text { regions }\end{array}$ & $\begin{array}{c}\text { Forests } \\
\%\end{array}$ & $\begin{array}{c}\text { Cultivated } \\
\text { areas } \%\end{array}$ & \begin{tabular}{|c|} 
Grass \\
lands \\
$(\%)$
\end{tabular} & \begin{tabular}{|c|} 
Built- \\
up \\
areas \%
\end{tabular} & $\begin{array}{c}\text { Miscellaneous } \\
\%\end{array}$ \\
\hline 1 & Aisne & $\begin{array}{c}\text { Grassland and } \\
\text { deciduous }\end{array}$ & 1 & 5 & 2 & 233283 & 117853 & Famenne & \multirow{9}{*}{41.9} & \multirow{9}{*}{14.5} & \multirow{9}{*}{38.2} & \multirow{9}{*}{2,6} & \multirow{9}{*}{2,7} \\
\hline 10 & Eau blanche & Grassland & 2 & 3 & 2 & 143936 & 81251 & Famenne & & & & & \\
\hline 12 & Eau de Somme & $\begin{array}{c}\text { Grassland and } \\
\text { deciduous }\end{array}$ & 1 & 4 & 2 & 224861 & 115248 & Famenne & & & & & \\
\hline 22 & Lembre & $\begin{array}{c}\text { Grassland and } \\
\text { deciduous }\end{array}$ & 1 & 4 & 1 & 233090 & 120961 & Famenne & & & & & \\
\hline 24 & LhommeEprave & Grassland & 3 & 5 & 3 & 206853 & 92337 & Famenne & & & & & \\
\hline 28 & MarchetteHotton & $\begin{array}{c}\text { Grassland and } \\
\text { deciduous }\end{array}$ & 3 & 4 & 1 & 223047 & 109972 & Famenne & & & & & \\
\hline 29 & MarchetteMarche & $\begin{array}{c}\text { Grassland and } \\
\text { deciduous }\end{array}$ & 3 & 2 & 2 & 219483 & 105054 & Famenne & & & & & \\
\hline 56 & Vieux fourneau & $\begin{array}{c}\text { Grassland and } \\
\text { deciduous }\end{array}$ & 1 & 3 & 1 & 235227 & 118319 & Famenne & & & & & \\
\hline 58 & Viroin & Grassland & 3 & 5 & 3 & 173117 & 86973 & Famenne & & & & & \\
\hline 21 & Lamframba & Deciduous forest & 2 & 1 & & 231118 & 33503 & \begin{tabular}{|l|} 
Jurassic \\
\end{tabular} & \multirow{11}{*}{38.6} & \multirow{11}{*}{10.4} & \multirow{11}{*}{43.9} & \multirow{11}{*}{3,3} & \multirow{11}{*}{3,8} \\
\hline 27 & Marche & Deciduous forest & 3 & 4 & 4 & 218404 & 33636 & Jurassic & & & & & \\
\hline 4 & Messancy & Urbanized area & 3 & 4 & 2 & 255725 & 29033 & Jurassic & & & & & \\
\hline 42 & Rabais & Deciduous forest & 2 & 4 & 2 & 235994 & 32482 & Jurassic & & & & & \\
\hline 44 & Tremble & $\begin{array}{c}\text { Grassland and } \\
\text { deciduous }\end{array}$ & & 4 & 2 & 207553 & 42680 & Jurassic & & & & & \\
\hline 47 & SemoisEt & $\begin{array}{l}\text { Grassland and } \\
\text { deciduous }\end{array}$ & & 5 & 3 & 240750 & 40204 & Jurassic & & & & & \\
\hline 48 & SemoisVa & Grassland & 3 & 5 & 3 & 243458 & 40207 & Jurassic & & & & & \\
\hline 50 & SemoisLacui & $\begin{array}{c}\text { Grassland and } \\
\text { deciduous }\end{array}$ & 3 & 4 & 3 & 218977 & 44853 & Jurassic & & & & & \\
\hline 51 & SemoisTint & Urbanized area & 3 & 4 & 3 & 232601 & 42060 & Jurassic & & & & & \\
\hline 54 & Ton & Urbanized area & 3 & 4 & 3 & 230013 & 24351 & Jurassic & & & & & \\
\hline 57 & Vire & Grassland & 4 & 4 & 4 & 239095 & 27244 & Jurassic & & & & & \\
\hline
\end{tabular}

\begin{tabular}{|c|c|c|c|c|c|c|c|c|c|c|c|c|c|}
\hline $\mathrm{N}^{\circ}$ & Water courses & land cover & luminosity & $\begin{array}{l}\text { stream } \\
\text { width } \\
\text { classes }\end{array}$ & $\begin{array}{l}\text { stream } \\
\text { depth } \\
\text { classes }\end{array}$ & $\mathrm{x}$ & $\mathrm{y}$ & $\begin{array}{l}\text { Natural } \\
\text { regions }\end{array}$ & $\begin{array}{c}\text { Forests } \\
\%\end{array}$ & $\begin{array}{c}\text { Cultivated } \\
\text { areas \% }\end{array}$ & \begin{tabular}{|c|} 
Grass \\
lands \\
$(\%)$
\end{tabular} & \begin{tabular}{|c|} 
Built- \\
up \\
areas \\
$\%$ \\
\end{tabular} & $\begin{array}{c}\text { Miscellaneous } \\
\%\end{array}$ \\
\hline 9 & $\begin{array}{c}\text { Dendre } \\
\text { orientale }\end{array}$ & Urbanized area & 2 & 4 & 2 & 110644 & 144546 & \begin{tabular}{|c|} 
Loess \\
low \\
plateaux
\end{tabular} & \multirow{10}{*}{10.8} & \multirow{10}{*}{57.3} & \multirow{10}{*}{17.7} & \multirow{10}{*}{10.5} & \multirow{10}{*}{3,7} \\
\hline 13 & Geer & $\begin{array}{l}\text { Grassland and } \\
\text { deciduous }\end{array}$ & 2 & 5 & 4 & 210935 & 153175 & \begin{tabular}{|c|} 
Loess \\
low \\
plateaux
\end{tabular} & & & & & \\
\hline 14 & Glabais & Grassland & 2 & 2 & 2 & 173343 & 155967 & \begin{tabular}{|c|} 
Loess \\
low \\
plateaux
\end{tabular} & & & & & \\
\hline 15 & Grandegette & Urbanized area & 3 & 4 & 3 & 186577 & 161291 & \begin{tabular}{|c|} 
Loess \\
low \\
plateaux
\end{tabular} & & & & & \\
\hline 16 & $\begin{array}{c}\text { Grande } \\
\text { Honnelle }\end{array}$ & Grassland & 3 & 4 & 4 & 101519 & 119832 & \begin{tabular}{|c|} 
Loess \\
low \\
plateaux
\end{tabular} & & & & & \\
\hline & Hain & Grassland & 3 & 3 & 2 & 141108 & 151940 & \begin{tabular}{|c|} 
Loess \\
low \\
plateaux
\end{tabular} & & & & & \\
\hline 31 & MehaiEmbre & Grassland & 3 & 4 & 3 & 197885 & 146491 & \begin{tabular}{|c|} 
Loess \\
low \\
plateaux
\end{tabular} & & & & & \\
\hline 32 & MehaiMoh & Urbanized area & 2 & 5 & 2 & 207878 & 138053 & $\begin{array}{c}\text { Loess } \\
\text { low } \\
\text { plateaux }\end{array}$ & & & & & \\
\hline 43 & Rhosnes & Grassland & 3 & 4 & 3 & 86198 & 161185 & \begin{tabular}{|c|} 
Loess \\
low \\
plateaux
\end{tabular} & & & & & \\
\hline 52 & SenneQuena & $\begin{array}{l}\text { Grassland and } \\
\text { deciduous }\end{array}$ & 3 & 3 & 1 & 135145 & 151052 & \begin{tabular}{|c|} 
Loess \\
low \\
plateaux
\end{tabular} & & & & & \\
\hline
\end{tabular}

Electronic appendix 1. The Sampling sites: geographical situation and land cover (To: Sossey K \& Rosillon F. Macrophytic distribution and trophic state of some natural and impacted watercourses - Belgium Wallonia.) 


\begin{tabular}{|c|c|}
\hline Abbreviations & Full name \\
\hline Ambflu & $\begin{array}{l}\text { Hygrohygroamblystegium fluviatile } \\
\text { (Hedw.) Loeske }\end{array}$ \\
\hline & Callitriche hamulata (Kütz. \\
\hline Calham & Koch); \\
\hline Calpla & Callitriche platycarpa (Kütz.) \\
\hline Chipol & $\begin{array}{l}\text { Chiloscyphus polyanthus (L.) Corda } \\
\text { Cladophora glomerata (Linnaeus) }\end{array}$ \\
\hline Claglo & Kützing. \\
\hline Crafil & $\begin{array}{l}\text { Spruce. } \\
\text { Cinclidotus fontinaloides (Hedw.) }\end{array}$ \\
\hline Cinfon & $\begin{array}{l}\text { P. Beauv. } \\
\text { Cinclidotus riparius (Web. E Mohr) }\end{array}$ \\
\hline Cinrip & Arnott \\
\hline Elonat & $\begin{array}{l}\text { Elodea nuttallii (Planchon) St John } \\
\text { Fissidens crassipes (Wilson ex }\end{array}$ \\
\hline Fiscras & Bruch et Schimp.) \\
\hline Fonant & Fontinalis antipyretica (Hedw.) \\
\hline Fonsqu & $\begin{array}{l}\text { Fontinalis squamosa (Hedw.) } \\
\text { Lemanea fluviatilis (Linnaeus) C. }\end{array}$ \\
\hline Leaspx & Agardh \\
\hline Lemmin & $\begin{array}{l}\text { Lemna minor L. } \\
\text { Leptodictyum riparium (Hedw.) }\end{array}$ \\
\hline Leprip & Warnst \\
\hline Myrspi & Myriophyllum spicatum L. \\
\hline Oedogonium $s p$ & Oedogonium sp. Link \\
\hline & Palustriella commutata (Hedw. ) \\
\hline Palucom & Ochyra \\
\hline Pelend & Pellia endiviifolia (Dicks.) Dumort. \\
\hline Potcris & Potamogeton crispus L. \\
\hline Potpec & Potamogeton pectinatus $L$. \\
\hline Ranflu & $\begin{array}{l}\text { Ranunculus fluitans Lam. } \\
\text { Ranunculus penicillatus (Dum.) }\end{array}$ \\
\hline Ranpen & $\begin{array}{l}\text { Bab. } \\
\text { Platyhypnidium riparioides (Hedw.) }\end{array}$ \\
\hline Plarip & Dixon \\
\hline & Riccardia chamedryfolia (With.) \\
\hline Riccha & Grolle \\
\hline Spaeme & Sparganium emersum (Rehm.) \\
\hline & Stigeoclonium sp. Link (excluding \\
\hline Stigeoclonium tenue & S. tenue) \\
\hline Stigeoclonium sp & Stigeoclonium tenue Link \\
\hline Zanpal & Zannichellia palustris L. \\
\hline Vaucheria $s p$ & Vaucheria sp de Candolle \\
\hline
\end{tabular}

Electronic appendix 2. Sossey K \& Rosillon F. Macrophytic distribution and trophic state of some natural and impacted watercourses - Belgium Wallonia

\section{References}

[1] European Commission (2000) Directive 2000/60/EC. Establishing a framework for community action in the field of water policy. European Commission PECONS 3639/1/100 Rev 1. Luxembourg.

[2] Hering D, Meier C, Rawer-Jost C, Feld CK, Biss R, Zenker A, Sundermann A, Lohse S, Bohmer J (2004) Assessing streams in Germany with benthic invertebrates: selection of candidate metrics. Limnologica. 34: 398 - 415.

[3] Seddon B (1972) Aquatic macrophytes as limnological indicators. Freshwater Biology. 2: 107-130.
[4] De Lange L, Van Zon JCJ (1983) A system for the evaluation of aquatic biotopes based on the composition of the macrophyte vegetation. Biological Conservation. 25:273-284.

[5] Lehmann A, Lachavanne JB (1999) Changes in the water quality of Lake Geneva indicated by submerged macrophytes. Freshwater Biology. 42: 457-466.

[6] Vestergaard O, Sand-Jensen K (2000) Alkalinity and trophic state regulate aquatic plant distribution in Danish lakes. Aquatic Botany. 67: 85-107.

[7] Kohler A (1975) Submerse Makrophyten and ihre Gesellschaften als Indikatoren der Gewässerbelastung. Beitr. Naturk. Forsch. Südw. Dtl. 34: 149-159.

[8] Wiegleb G (1981) Application of multiple discriminant analysis on the analysis of the correlation between macrophyte vegetation and water quality in running waters of Central Europe. Hydrobiologia. 79: 91-100.

[9] Caffrey J (1986) Macrophytes as biological indicators of organic pollution in Irish rivers. In Richardson D. H. S. (ed.), Biological indicators of pollution Royal Irish Academy: 77-87.

[10] Muller S (1990) Une séquence de groupements végétaux bioindicateurs d'eutrophisation croissante des cours d'eau faiblement minéralisés des Basses Vosges gréseuses du Nord. CR Acad Sci Paris. 310(III): 509-514.

[11] Grasmuck N, Haury J, Leglize L, Muller S (1995) Assessment of the bio-indicator capacity of aquatic macrophytes using multivariate analysis. Hydrobiologia. 300-301: 115-122.

[12] Haury J (1996) Assessing functional typology involving water quality, physical features and macrophytes in a Normandy river. Hydrobiologia. 340: 43-49.

[13] Haury J, Jaffre M, Dutartre A, Peltre MC, Barbe J, Tremolieres M, uerlesquin M, Muller S (1998) Application of the standardized protocol "Milieu Et Vegetaux aquatiques fixes" to 12 French rivers: preliminary floristic typology. International Journal of Limnology. 34: 129-139.

[14] Thiebaut G, Muller S (1998) The impact of eutrophication on aquatic macrophyte diversity in weakly mineralised streams in the Northern Vosges mountains (NE France). Biodiversity Conservation. 7: 1051-1068.

[15] Riis T, Sand-Jensen K, Vestergaard O (2000) Plant communities in lowland Danish streams: species composition and environmental factors. Aquatic Botany. 66: 255-272.

[16] Vanderpoorten A (1999a) Aquatic bryophytes of a spatio-temporal monitoring of the water pollution of the rivers Meuse and Sambre (Belgium). Environ. Poll. 104: 401-410. 
[17] Vanderpoorten A (1999b) Correlative and experimental investigations on the segregation of aquatic bryophytes as a function of water chemestry in the Walloon hydrographic network. Lejeunia. 159: 1-9.

[18] Vanderpoorten A, Empain A (1999c) Morphologie, distribution et écologie comparées d'Amblystegium tenax et d'A. fluviatile en Belgique. Belg. J. Bot. 132: 3-12.

[19] Bouxin G (1995) Démarche conduisant à la mise au point d'une technique de description de la végétation des ruisseaux. Acta Bot. Gall. 142: 533-540.

[20] Bouxin G (1999) Description de la végétation aquatique et $\mathrm{du}$ bord de l'eau dans le bassin hydrographique de la Molignée (Condroz, Belgique) par l'analyse multiscalaire des motifs. Ecologie. 30: 139-163.

[21] Thoen D, Roussel L, Nicolas J (1996) Etudes des groupements macrophytes vasculaires aquatiques de la semois en rapport avec la qualité globale des eaux et du milieu. Ecologie. 27: 223-232.

[22] Haury J, Peltre MC, Tremolieres M, Barbe J, Thiebaut G, Berne I, Daniel H, Chatenet P, Muller S, Dutartre A, Laplace-Treyture C, Cazaubon A, LambertServien E (2002) A method involving macrophytes to assess water trophy and organic pollution: the Macrophyte Biological Index for Rivers (IBMR) application to different types of rivers and pollutions. In Dutartre MH. Montel (eds), Proc.11th EWRS International Symposium on Aquatic Weeds, Moliets Et Maa, France: 247-250.

[23] Haury J, Peltre MC, Tremolieres M, Barbe J , Thiebaut G, Bernez I, Daniel H, Chatenet P, Haan-Archipof G, Muller S, Dutartre A, Laplace-Treyture C, Cazaubon A, Lambert-Servien E (2006) Agrocampus Rennes, UMR INRA. A new method to assess water trophy and organic pollution - the Macrophyte Biological Index for Rivers (IBMR): its application to different types of river and pollution. Hydrobiologia. 570: 153-158.

[24] Vanden Bossche JP \& Usseglio-olatera P (2005) Characterization, ecological status and type-specific reference conditions of surface water bodies in Wallonia (Belgium) using biocenotic metrics baside on benthic invertebrate communities. Hydrologia. 551: 253-271

[25] Lambinon J, Delvosalle L, Duvigneaud J, (et coll.) (2012) Nouvelle flore de la Belgique, du GrandDuché de Luxembourg, du Nord de la France et des régions voisines (Ptéridophytes et Spermatophytes). Cinquième et sixième Edition. Meise, Jardin Botanique National de Belgique.

[26] Smith A.J.E (2008) The moss flora of Britain and Ireland. Second edition. Cambridge, Cambridge University Press.

[27] John D.M, Whitton B.A \& Brook A.J (2011) The Freshwater Algal Flora of the British Isles. An identification guide to freshwater and terrestrial algae. Cambridge, Cambridge university Press.
[28] McCune B, Grace J. B (2002) Analysis of Ecological Communities. MJM Software Design. Gleneden Beach. Oregon. USA.

[29] Dufrêne M, Legendre P (1997) Species assemblages and indicator species: the need for a flexible asymmetrical approach. Ecological. Monographs. 67: 345-366.

[30] Claveri B (1995) Les bryophytes aquatiques comme traceurs de la contamination métallique des eaux continentales. Thèse Doc. Univ. Metz. 235p.

[31] Vanderpoorten A, Ector L, Hoffmann L (2000) Chemical profiles of Amblystegium riparium, Fontinalis antipyritica and Rhynchostegium riparioides in the Grand-Duchy of Luxemburg. Nova Hedwigia. 71: 209-221.

[32] Werner C (2001) Aquatic bryophytes in Luxembourg rivers. Bull.Soc. Nat. Luxemb. 101: 3-18.

[33] Birk S, Willby N (2010) Towards harmonization of ecological quality classification: establishing common groups in European macrophytes assessment for rivers. Hydrobiologia. 652: 149-163.

[34] Dethioux M (1991) Les cours d'eau de Wallonie: Caractéristiques physiques et floristiques - Principes et techniques de verduration. Institut pour l'encouragement de la Recherche Scientifique dans l'Industrie et l'Agriculture (I.R.S.I.A.).

[35] Carbiener R, Trémolières M, Muller S (1995). Végétation des eaux courantes et qualité des eaux: une thèse, des débats, des perspectives. Acta bot. Gallica. 142: 489-531.

[36] Meltzer A, Exler D (1982) Nitrate reductase acivities in aquatic macrophytes. In studies on aquatic vascular plants, Symoens JJ., Hooper SS, Compère P., eds., Royal Botanical Society of Belgium, Brussels: 128-135

[37] Petts GE (1984a) Impounded Rivers. Perspectives for Ecological Management. John Wiley and Sons, Chichester: 326.

[38] Brookes A (1988) Channelized Rivers, Perspectives for Environmental Management. John Wiley \& Sons. Chichester.

[39] Haslam SM (1978) River Plants: The macrophytic vegetation of watercourses. Cambridge University Press, Cambridge.

[40] Fox AM (1992) Macrophytes. In Calow P, Petts GE (eds), The Rivers Handbook Hydrological and Ecological Principles. Blackwell Scientific Publications. Oxford: 216-233.

[41] Petts GE (1984b) Vegetation reaction and structure, Impounded Rivers: Perspectives for Ecological Management. John Wiley \& Sons, Chichester: 150173.

[42] Baattrup-Pedersen A, Riis T (1999) Macrophyte diversity and composition in relation to substratum characteristics in regulated and unregulated Danish streams. Freshwater Biology. 42: 375-385. 
[43] Manolaki P, Papastergiadou E (2013) The impact of environmental factors on the distribution pattern of aquatic macrophytes in a middle-sized Mediterranean stream. Aquatic Botany. 104: 34-46.

[44] Abou-Handman H, Haury J, Hebrard JP, Dandelot S, Cazaubon A (2005) Macrophytic communities inhabiting the Huveaune (South-East France), a river subject to natural and anthropic distrurbance. Hydrobiologia. 551:161-170.
[45] Sraj-Krzic N, Germ M, Urbanc-Bercic O, Kuhar U, Janauer G.A, Gabers scik A (2007) The quality of the aquatic environment and macrophytes of karstic watercourses. Plant Ecology. 192: 107-118.

[46] O'Hare MT, Baattrup-Pedersen A, Nijboer R, Szoszkiewicz K \& Ferreira T (2006) Macrophyte communities of European streams with altered physical habitat. Hydrobiologia. 566: 197-210. 